\title{
Effect of Rates and Frequency of Application of Methiocarb as a Bird Repellent on Sorghum ${ }^{1}$
}

\begin{abstract}
A. Sotomayor-Ríos ${ }^{2}$
ABSTRACT

The capacity of methiocarb [as Mesurol, which includes 3,5-dimethyl4(methylthio) phenol methylcarbamate] as a bird repellent on a yellow endosperm grain sorghum (Sorghum bicolor (L.) Moench) hybrid, DeKalb C-42y, was evaluated. Methiocarb was applied to the grain heads from July 8 to August 5 at frequencies of $1,2,3$, and 4 weeks and at rates of 2 and $4 \mathrm{~kg} / \mathrm{ha}$. After the grain was harvested, germination percentages were determined on all treatments during a 3-week period. A separate treatment, labeled external control, $W_{0} R_{0}(e)$, was planted $15 \mathrm{~m}$ distant from the main experiment and was compared to the internal control of the main plot, $W_{0} R_{0}(i)$. No statistical differences were observed among treatments in terms of total grain yield, threshing percentage, and the other characters when the control plot $W_{0} R_{0}$ (i) was compared with the remaining treatments. Birds caused considerably more damage on the external than on interior plots in weight of 25 heads and threshing percentage. The germination percentage of seed treated with methiocarb was statistically superior to that of the untreated seed.
\end{abstract}

\section{INTRODUCTION}

Birds in all locations where sorghum is grown in Puerto Rico, cause considerable damage from the milk stage to maturity. The most destructive birds feeding on sorghum at the milk stage are the sparrows (Fringillidae family), whereas blackbirds, such as yellow-shouldered and red-winged grackles (Icteridae family), are more destructive when the grain matures.

The grain sorghums most susceptible to bird damage are the white-, red- and yellow-seeded varieties, while the brown types are the most resistant. Published data support the correlation between bird resistance and the brown, high-tannin sorghums (5). However, it has also been shown that tannins reduce the biological value of grain sorghum for monogastric animals (1), and sorghums with good bird resistance and high tannic acid are not desirable for human food.

To protect grain sorghums from bird damage, breeders and farmers have used various devices, none of which have resulted in complete control throughout the grain filling period. The plant breeder's normal practice is to bag each head after flowering, a tedious and uneconomical job. Even when heads are bagged properly, they are easily opened by blackbirds. During the early soft-dough stage, sorghum heads left unprotected receive considerable damage from finches, sparrows and other small birds.

${ }^{1}$ Manuscript submitted to Editorial Board November 29, 1976.

${ }^{2}$ Research Geneticist, Mayagüez Institute of Tropical Agriculture, Agricultural Research Service, USDA, Mayagüez, P. R. 00708. 
There are few reports available concerning effective methods for the control of bird damage in the tropics and subtropics. Metser and Royall (4) reported that $42 \%$ micronized thiram (tetra methyl thiram disulfide) (as Arasan $42-\mathrm{S}^{3}$ ) at concentrations of 1 to $5 \%$ was the most effective treatment for repelling English sparrows in Texas. Methiocarb was tried on mature grain sorghums by Faris (2) in the northeast of Brazil but gave poor results against certain bird species. Mott and Lewis (6) reported that an aerial spray of $3.36 \mathrm{~kg} / \mathrm{ha}(3.0 \mathrm{lb} / \mathrm{acre})$ of methiocarb reduced significantly blackbird damage to ripening grain sorghum at Columbia, S. D. In Colorado and Oklahoma, Guarino (3) reported that methiocarb effectively reduced damage caused by red-winged blackbirds and grackles.

The objectives of this study were to evaluate the possibility of using methiocarb as a bird repellent and its effect on the germination of harvested seed treated with this chemical.

\section{MATERIALS AND METHODS}

The field experiment was conducted near Isabela, Puerto Rico, at the Isabela Experiment Farm of the Mayagüez Institute of Tropical Agriculture (MITA), ARS-USDA, which is located about $128 \mathrm{~m}$ above sea level and with temperature ranging from $18^{\circ} \mathrm{C}$ to $31^{\circ} \mathrm{C}$. The soil is a Coto clay with $\mathrm{pH} 5.32$. A 15-5-10 fertilizer at the rate of $560 \mathrm{~kg} / \mathrm{ha}$ was applied before and 30 days after planting. Propazine [2-chloro-4,6bis(isopropylamino) ${ }_{-} S$-triazine] at the rate of $3 \mathrm{~kg} / \mathrm{ha}$ was applied to all plots immediately after planting. Overhead irrigation was applied to all plots whenever it was necessary.

The experimental design was a split plot with five frequencies of application of methiocarb (control and every 1, 2, 3, and 4 weeks) tested in the main plots and two rates of application ( 2 and $4 \mathrm{~kg} / \mathrm{ha}$ ) in the subplots. The subplot treatment description for the frequency and rate of application was as follows: $W_{0} R_{0}-$ control; $W_{1} R_{1}$-weekly, $2 \mathrm{~kg} / \mathrm{ha}$; $\mathrm{W}_{1} \mathrm{R}_{2}$-weekly, $4 \mathrm{~kg} / \mathrm{ha}$; $\mathrm{W}_{2} \mathrm{R}_{1}$ - every 2 weeks, $2 \mathrm{~kg} / \mathrm{ha}$; $\mathrm{W}_{2} \mathrm{R}_{2}$ - every 2 weeks, $4 \mathrm{~kg} / \mathrm{ha}$; $\mathrm{W}_{3} \mathrm{R}_{1}$ - every 3 weeks, $2 \mathrm{~kg} / \mathrm{ha} ; \mathrm{W}_{3} \mathrm{R}_{2}$ - every 3 weeks, 4 $\mathrm{kg} / \mathrm{ha} ; \mathrm{W}_{4} \mathrm{R}_{1}$ - every 4 weeks, $2 \mathrm{~kg} / \mathrm{ha} ; \mathrm{W}_{4} \mathrm{R}_{2}$ - every 4 weeks, $4 \mathrm{~kg} / \mathrm{ha}$; $W_{0} R_{0}$ (i)-internal control-main experiment; $W_{0} R_{0}$ (e)-external control- plots established $15 \mathrm{~m}$ away from the main experiment. Methiocarb and an adhesive were applied to the sorghum heads from July 8 to August 5 with a 1.9-1 hand sprayer.

Field plots were planted with DeKalb C-42y yellow endosperm sorghum on May 14, 1975, at the rate of about $8 \mathrm{~kg}$ seed/ha. Subplot size

\footnotetext{
${ }^{3}$ Trade names are used in this publication solely for the purpose of providing specific information. Mention of a trade name does not constitute a guarantee or warranty of equipment or materials by the Agricultural Experiment Station of the University of Puerto Rico or an endorsement over other equipment or materials not mentioned.
} 
was four rows spaced $102 \mathrm{~cm}$ apart and $4 \mathrm{~m}$ in length. An additional planting of the control treatment was made on May 15, 1975, about $15 \mathrm{~m}$ east of the main experiment. This external plot consisted of four subplots with four rows, spaced $102 \mathrm{~cm}$ apart and $4 \mathrm{~m}$ in length. This planting is designated the external control, $W_{0} R_{0}$ (e), as compared to the internal control $W_{0} R_{0}(i)$, of the main experiment. At the end of the fifth methiocarb application (August 5, 1975) plots were rated by visual inspection according to the amount of bird feeding, as follows: $0=$ none; $1=$ none to light; $2=$ light to moderate; $4=$ moderate to heavy; $5=$ heavy. The two center rows were harvested after the visual rating was completed, and data were collected on total grain weight at $14 \%$ moisture, weight of 25 heads, and threshing percentage. Samples from each treatment were used for three germination tests conducted at weekly intervals, placing 100 seeds on petri dishes and allowing them to germinate at room temperature, to study the effect of methiocarb on seed germination.

The mean weight of 25 heads and threshing percentage of the internal and external control plots were compared in a $t$ test. The yield data, threshing percent, weight of 25 heads, observed feeding, and germination tests were evaluated with Duncan's multiple range test.

\section{RESULTS AND DISCUSSION}

Table 1 presents the effect of methiocarb on the yield, threshing percentage, weight of 25 heads, and observed feeding of birds.

Grain yield ranged from 8,457 to $7,054 \mathrm{~kg} / \mathrm{ha}$ (table 1). The highest yield was observed when methiocarb was applied every 2 weeks at the 4 $\mathrm{kg} / \mathrm{ha}$ rate $\left(\mathrm{W}_{2} \mathrm{R}_{2}\right)$, although it was not statistically different from any other treatments except every 3 weeks at $2 \mathrm{~kg} / \mathrm{ha}\left(\mathrm{W}_{3} R_{1}\right)$. The yield of the internal control plots $W_{0} R_{0}$ (i) was not statistically different from yields in the lowest and highest producing plots. Methiocarb had little or no effect on the total grain production.

In regard to threshing percentage only $\mathrm{W}_{3} \mathrm{R}_{1}$ was significantly different from all but the control plot and $W_{1} R_{2}$. The threshing percentage of the control plot was not statistically different from the remaining treatments.

No statistical differences were observed among weights of 25 heads. The mean visual ratings of observed feeding of birds were not statistically different.

A $t$ test showed significantly higher weight of 25 heads and threshing percentage in the internal control plot than in the external control plots. Apparently birds were more active on the external plot than on the internal control, where nearby plots had been sprayed with methiocarb. These results might be of help in the future planning of experiments, in 
which chemicals are to be evaluated for the control of bird damage on grain sorghum.

The effect of methiocarb on the germination percentages of DeKalb C$42 y$ during a 3-week interval ranged from 91.21 to $86.21,91.42$ to 80.18 , and 91.25 to 86.00 during the first, second, and third week, respectively. No statistical differences were observed among the means of the methiocarb treatments, but in all cases they were significantly higher than those of the $\mathrm{W}_{0} \mathrm{R}_{0}$ (i) treatment $(\mathrm{P}<.05)$.

Studies underway at this Institute indicate that the presence of fungal pathogens in sorghum grain is related to poor seed germination. In this experiment, methiocarb probably acted as a fungicide and helped seeds from the treated plots to germinate significantly better than those from the nonsprayed plots.

TABLE 1. -Effect of methiocarb on mean yield, threshing percentage, weight of 25 grain heads, and mean feeding of birds on DeKalb C-42y hybrid sorghum

\begin{tabular}{ccccc}
\hline Treatment & Yield & Threshing & Weight of 25 heads Observed feeding \\
\hline & Kg/ha & $\%$ & $G$ & \\
$\mathrm{~W}_{2} \mathrm{R}_{2}$ & $8,457 \mathrm{a}^{1}$ & $76.35 \mathrm{a}$ & 1,801 & $3.51^{2}$ \\
$\mathrm{~W}_{2} \mathrm{R}_{1}$ & $8,057 \mathrm{ab}$ & $76.94 \mathrm{a}$ & 1,827 & 3.01 \\
$\mathrm{~W}_{1} \mathrm{R}_{1}$ & $7,778 \mathrm{ab}$ & $76.88 \mathrm{a}$ & 1,834 & 2.95 \\
$\mathrm{~W}_{4} \mathrm{R}_{2}$ & $7,700 \mathrm{ab}$ & $77.26 \mathrm{a}$ & 1,628 & 3.51 \\
$\mathrm{~W}_{4} \mathrm{R}_{1}$ & $7,621 \mathrm{ab}$ & $76.09 \mathrm{a}$ & 1,561 & 3.20 \\
$\mathrm{~W}_{0} \mathrm{R}_{0}(\mathrm{i})$ & $7,542 \mathrm{ab}$ & $71.82 \mathrm{ab}$ & 1,797 & 3.98 \\
$\mathrm{~W}_{3} \mathrm{R}_{2}$ & $7,247 \mathrm{ab}$ & $75.23 \mathrm{a}$ & 1,698 & 3.45 \\
$\mathrm{~W}_{1} \mathrm{R}_{2}$ & $7,202 \mathrm{ab}$ & $73.06 \mathrm{ab}$ & 1,628 & 2.95 \\
$\mathrm{~W}_{3} \mathrm{R}_{1}$ & $7,054 \mathrm{~b}$ & $65.69 \mathrm{~b}$ & 1,707 & 3.20 \\
\hline
\end{tabular}

1 Means in a column followed by one or more letters in common do not differ significantly at $(\mathrm{P}<.05)$, by Duncan's multiple range test.

${ }^{2} 0=$ none; $1=$ none to light; $2=$ light; $3=$ light to moderate; $4=$ moderate to heavy; $5=$ heavy.

\section{RESUMEN}

Un experimento se llevó a cabo en la finca experimental de Isabela del Instituto Mayagüezano de Agricultura Tropical del Departamento de Agricultura de los Estados Unidos, con el propósito de evaluar en un sorgo de grano el efecto de methiocarb a dos niveles (2 y $4 \mathrm{~kg}$./ha.) aplicándose éste cada 1,2 , 3 y 4 semanas, respectivamente. Se sembró un híbrido de endosperma amarillo, 'DeKalb C-42y' en parcelas de cuatro surcos, $4 \mathrm{~m}$. de largo a distancia de $102 \mathrm{~cm}$. y se utilizó un diseño de parcelas divididas. Cada tratamiento se repitió cuatro veces. Se llevó a cabo además un estudio para determinar el efecto del methiocarb en el porcentaje de germinación de la semilla en un perído de tres semanas.

Se establecieron parcelas adicionales del tratamiento que no recibió methiocarb (control) a $15 \mathrm{~m}$. al este del experimento principal. Estas parcelas se identificaron como control externo en contraste con las del control interno. Se estudió la producción de grano, porcentaje de rendimiento y peso de 25 espigas. Luego de la última aplicación de methiocarb todas las parcelas se evaluaron visualmente con una escala del 0 al 5 , siendo 5 la condición de mayor daño el de los pájaros.

Los resultados indican que las aplicaciones de methiocarb no redujeron significativamente el efecto de Ios daños causados por los pájaros. Se concluyó que en los tratamientos adyacentes al control interno la aplicación de methiocarb fue beneficiosa, razón por la 
caul no se encontraron diferencias significativas entre éste y los demás tratamientos. Se observó un efecto significativo de ataque de pájaros en las parcelas establecidas fuera del límite de la aplicación del methiocarb (control externo). Los pesos de 25 espigas y el porcentaje de rendimiento fueron estadísticamente inferiores en el control externo al compararse con el control interno en una prueba de $t$.

El porcentaje de germinación de la semilla aumentó significativamente cuando éstas se trataron con methiocarb. Los resultados fueron consistentes en las tres pruebas realizadas cada semana.

\section{LITERATURE CITED}

1. Axtell, J. D., Mohan, D. P., and Cummings, D. P., Genetic improvement of biological efficiency and protein quality in sorghum, Proc. 29th Annu. Corn and Sorghum Res. Conf. 29-39, 1974.

2. Faris, Mohamed A. E., The general bird problem in grain sorghum, Int. Sorghum Workshop, Mayagüez Campus, Univ. P.R., Jan. 7-11, 1975.

3. Guarino, J. L., Methiocarb, a chemical bird repellent: A review of its status and uses, Denver Wildlife Res. Cen., 1971.

4. Metzer, R., and Royall, W. C., Jr., Field tests of three chemicals as bird repellents on mature grain sorghum, Texas Agric. Exp. Sta., College Station, Tex. MP-524, June 1961.

5. McMilliam, W. W., Wiseman, B. R., Burns, R. E., Harris, H. B., and Greene, G. L., Bird resistance in diverse germplasm of sorghum, Agron. J. 64: 821-2, 1972.

6. Mott, D. F. and Lewis, L. E., An evaluation of an aerial application of methiocarb for protecting ripening grain sorghums from blackbirds at Sun Lake National Wildlife Refuge, South Dakota, Report of Study No. 57, Work Unit DF-102.3, Denver Wildlife Res. Cen., January 1975. 